\title{
Mechanical Behavior of Modified Reactive Powder Concrete with Waste Materials Powder Replacement
}

\author{
Mushtaq Sadiq Radhi ${ }^{{ }^{1}}$, Zainab M. R. Abdul Rasoul ${ }^{1}$, Aymen J. Alsaad ${ }^{1}$ \\ ${ }^{1}$ Department of Civil Engineering, College of Engineering, University of Kerbala, 56001, Karbala, Iraq \\ * Corresponding author, e-mail: mushtaq.sadiq@uokerbala.edu.iq
}

Received: 03 October 2020, Accepted: 08 February 2021, Published online: 19 February 2021

\begin{abstract}
Across the world, a huge amount of waste materials is deposited from different industrial or construction activities. Out of this massive waste quantity, a petite is recycled and remaining is dumped in vulnerable lands. This paper deals with the potential utilization of solid waste in reactive powder concrete, practically powdered glass originating from waste glass bottles and powdered ceramics tile from waste of construction process. First, the optimum ratio of waste pozzolanic material (ceramics to glass ratio) was obtained by pozzolinic activity test. Then, the optimal waste pozzolanic material was incorporated in reactive powder concrete at several substitution levels. The waste pozzolanic material in 5\%, $10 \%, 15 \%, 20 \%$, and $25 \%$ were added in the reactive powder concrete mixes as fractional supplement of silica fume. Strength and water absorption of the modified reactive powder concrete were evaluated. A significant enhancement was observed in mechanical behavior of modified reactive powder concrete containing $15 \%$ waste pozzolanic material. Results directed irrelevant raise in water absorption as increasing the waste replacement material.
\end{abstract}

Keywords

high strength concrete, mechanical performance, microsilica, sustainable, waste cementitious

\section{Introduction}

The incorporation of very fine ingredients such silica fume and other fine materials into the concrete matrix to improve pozzolanic activity and particles condensing, joined with a utilization of superplasticizer for reducing water to binder ratio have motivated the improvement of an inventive type of cement based materials identified as reactive powder concrete (RPC) [1].

The basics of reactive powder concrete were presented in a research by Richard and Cheyrezy [2]. Basically, reactive powder concrete has many advantages compared to conventional cement based materials, including increased particles size homogeneity and microstructure condensing owing to elimination of the coarse aggregate and usage of very fine sand $(150-600 \mu \mathrm{m})$, reduced water to binder ratio lesser than 0.2 by utilization superplasticizer which noticeably increased reactive powder concrete mechanical behavior. Extremely, reducing the volume of the cement paste pores and increased reactivity due to the high fraction addition of silica fume accelerates the pozzolanic reaction to produce extra hydrate of calcium silicate. Adequately dispersed steel fibers serves as rigid constituents in the cementitious matrix for improving the mechanical behavior of reactive powder concrete, primarily elastic modulus, tensile strength, and ductility. Enhancing the microstructure by accelerating the hydration of cement as result of subjecting pressure at fresh stage and special curing regime [3-5].

Large quantities of waste materials like clay bricks, glass, concrete and mortar are produced from construction or demolition process. The use of these waste to manufacture recycled building materials is both an economical process of disposal and environmentally friendly.

Recycled powders are created from waste construction and demolition, and reused to manufacture green building materials by smashing, grinding, drying, and grading [6-12]. Many researchers have revealed that waste materials like glass or pottery clay has potential for using as building materials. Zhu et al. [13] inspected $10 \%, 20 \%$, and $30 \%$ cement replacement in the reactive powder concrete by powered clay bricks. It was found that the mechanical properties of recycled reactive powder concrete improved at first and then reduced as the replacement proportion increased. The $10 \%$ replacement 
proportion was recommended. In an another study implemented by Kushartomo et al. [14] to examine the impact of $10 \%, 20 \%, 30 \%$ of waste powdered glass, as pozzolanic replacement, on the performance of the reactive powder concrete. The outcomes showed that the maximum improvement in the mechanical performance can be achieved at $20 \%$ replacement. Asteray et al. [15], Demiss et al. [16] and Asteray et al. [17] were performed studies to inspect the reactive powder concrete performance that adapted by incorporation different waste materials (fly ash, glass, and ceramic) as silica fume and sand replacement. The outcomes confirmed that the full replacing of the silica fume by combination of fly ash and powdered waste glass, $15 \%$ replacing of sand by powdered ceramics waste is a promising line for construction sector because of the improvement of the mechanical properties of adjusted reactive powder concrete. Mao et al. [18] investigated the utilization of powdered demolition materials (clay bricks and concrete) to substitute cement in reactive powder concrete. Tests outcomes directed that reactive powder concrete with replacement proportion up to $30 \%$ has adequate mechanical properties. Mohammed et al. [19] were produced recycled reactive powder concrete by incorporation crashed clay bricks as sand replacement up to $50 \%$. The experimental outcomes indicted that recycled reactive powder concrete properties were enhanced by replacement proportion up to $25 \%$. Islam and Yesmin [20] were implemented experimental research to examine the influence of use the waste materials (powdered glass, fly ash, and slag) as replacement from cement and silica fume in the reactive powder concrete. Test results showed that the mechanical properties slightly affected by replacement. Most recent study conducted by Liu et al. [21] to examine the employment of hazard waste materials (cathode ray tube glass) as sand replacement in reactive powder concrete. The findings of the study provided an operative alternative to reutilizing of this hazard waste without limitations on the replacement ratio and safety due to the satisfactory properties of the recycled reactive powder concrete.

The utilization of waste materials like waste clay bricks and waste glass as pozzolanic replacement in concrete or reactive powder concrete can diminish the quantity of these waste materials and increase the availability of locally pozzolanic materials. The main target of the present investigation was to examine the outcomes of co-utilization of two powdered waste materials (ceramics tiles and glass) as silica fume replacement on the mechanical behavior of reactive powder concrete. To achieve this objective, firstly, the optimal ratio between powdered waste glass and powdered recycled clay bricks was found. Then, new waste pozzolanic material was substituted from silica fume at different percentages. Lastly, the mechanical behavior of modified reactive powder concrete was measured.

\section{Experimental work}

\subsection{Materials}

\subsubsection{Silica fume}

A silica fume as cement replacement used to produce concrete with high performance properties. Micro silica fume with trademark Conmix was utilized in this study, which has activity index $140 \%$ based on accelerated method at 7 days. The requirements of the silica fume complied to ASTM C-1240 [22].

\subsubsection{Cement}

The adopted cement in this study was type I Portland cement with trademark Karasta-Lafarage. This cement obeys to ASTM C-150 [23] in terms of chemical properties and physical properties.

\subsubsection{Fine aggregate}

Natural fine aggregate with maximum size particles $0.6 \mathrm{~mm}$ was unitized in this investigation. The grading of this fine aggregate comply with ASTM C-33 [24] grading.

\subsubsection{Waste glass}

A glass is amorphous solid with silica content ranged between $60 \%$ to $80 \%$ [25]. The adopted glass in this study was collected from waste glass bottles, which fabricated from soda- lime glass the most communal commercial glass. The typical chemical composition of this glass type is silica ranged between $70 \%$ and $75 \%$, and the remaining constituents are sodium oxide, and lime.

\subsubsection{Waste ceramic tiles}

Ceramic tile compositions mainly comprise silica about $70 \%$ and alumina about $20 \%$. This contents not fully crystalline and may present in amorphous state with pozzolanic activity [26]. The adopted ceramic waste was collected from waste materials of some building under construction.

\subsubsection{Chemical admixture}

A third generation super-plasticizer based on modified Polycarboxylates with trademark Sika Viscocrete 5930 was utilized in this study for increasing the flow of reactive powder concrete at a given water to binder ratio. This chemical admixture complies with requirements of ASTMC-494 (types F and G) [27]. 


\subsubsection{Water}

A potable water was used in this study for production and curing reactive powder concrete, that supplied from local city network.

\subsection{Preparation of waste powder}

Fineness of the pozzolanic material is key factor of its reactivity, as fineness increase the activity increased. To attain the required fineness at ASTM C-618 [28], the two waste materials (glass and ceramic tile) were individually prepared at three steps: first, manually crashed by hammer into small size. Then, these particles were grinded by loss angles machine for about $15 \mathrm{~min}$. Finally, the powdered waste materials were grinded by high velocity electrical grinder for further finesses. To achieve the homogenous between the powdered glass and powdered ceramic tile, the two powdered of waste materials were additionally grinded together by electrical grinder for each powered ceramic tile to powdered waste glass ratio.

The activity index, according to ASTM C-311 [29], for waste pozzolanic materials was performed at different mixes of ceramic to glass (CG0, CG20, CG 40, CG60, and CG80) with fractions of ceramic to glass are $(0 \%, 20 \%, 40 \%$, $60 \%, 80 \%$ ), respectively, to attain an optimum mixing ratio for the proposed pozzolanic material. The pozzolanic activity outcomes revealed that mix with $20 \%$ powdered waste ceramic and $80 \%$ powdered waste glass (CG20) has the greatest index from the other mixes, as shown in Fig. 1.

\subsection{Mix proportion}

Control mix and five mixes are approved in the experimental plan of the research. The optimum proposed pozzolanic material (CG20) was utilized as partial volumetric replacement from silica fume content at fractions of $(5 \%$, $10 \%, 15 \%, 20 \%$, and $25 \%$ ). The proportion mix of control mix was stand on earlier local studies mixes [30-35]. The quantities of ingredients for mixes in this study are itemized in Table 1.

\subsection{Specimens preparation}

The preparation process of the modified reactive powder concrete was as the same as that clarified in reference [36]. First, the dry ingredients were mixed for $1 \mathrm{~min}$ in mortar mixer at low speed. Then, the water and super-plasticizer were added to mixer and mixed at high speed until achieve the required consistency. The well stirred mixtures were poured into steel molds (cubes and cylinders). Next, the

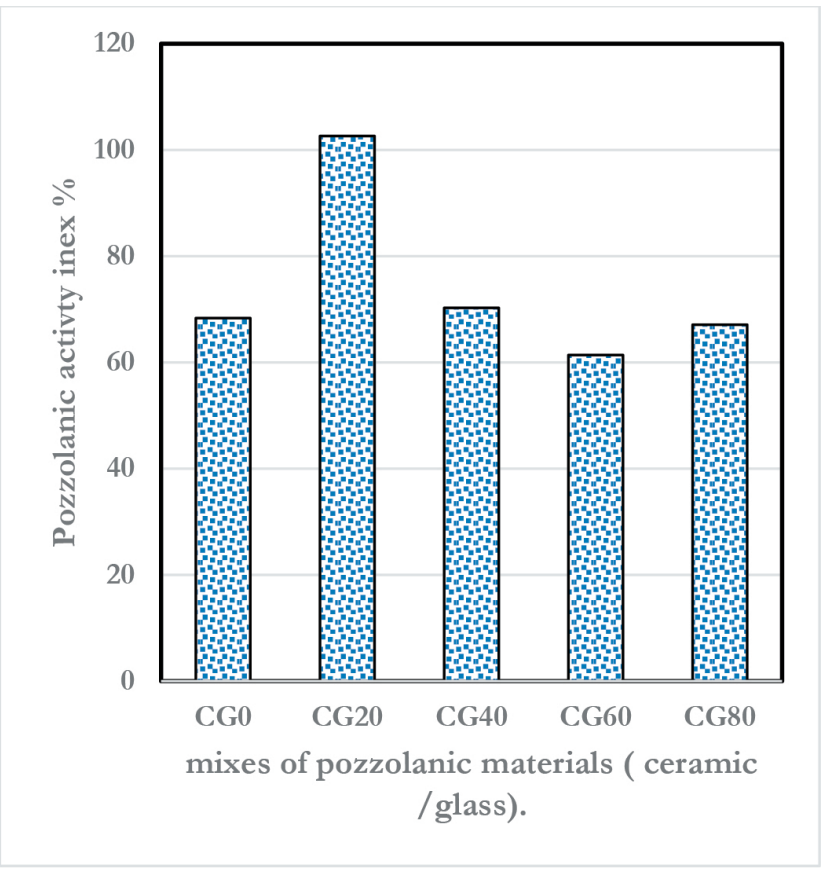

Fig. 1 Pozzolanic activity results for different ratio of waste ceramics to waste glass

Table 1 The proportion of all mixes

\begin{tabular}{lcccccc}
\hline $\begin{array}{l}\text { Material } \\
\mathrm{kg} / \mathrm{m}^{3}\end{array}$ & MIX00 & MIX05 & MIX10 & MIX15 & MIX20 & MIX25 \\
\hline Cement & 880 & 880 & 880 & 880 & 880 & 880 \\
Sand & 970 & 970 & 970 & 970 & 970 & 970 \\
S.F. & 220 & 209 & 198 & 187 & 176 & 165 \\
W.P(CG20) & 0 & 11 & 22 & 33 & 44 & 55 \\
Water & 154 & 154 & 154 & 154 & 154 & 154 \\
SP.\% & 3.2 & 3.4 & 3.7 & 3.9 & 4.1 & 4.4 \\
\hline
\end{tabular}

- S.F., silica fume, W.P. waste powdered (CG20)

- SP. super-plasticizer

filled molds were vibrated on the vibrating table, and then covered by nylon for $24 \mathrm{hr}$. Later, the molds were extracted and the specimens were water cured at temperature of $35 \pm 3^{\circ} \mathrm{C}$ till test.

\subsection{Measurement of mechanical behavior}

The mechanical behavior of modified reactive powder concrete was measured by compressive strength according to ASTM C-109 [37], and splitting strength according to ASTM C-496 [38]. $50 \mathrm{~mm}$ cubes were adopted for compressive test at ages 7, 28, 56 days (three cubes at each age test). Cylinders with $100 \mathrm{~mm}$ height and diameter were adopted for splitting test at ages 7, 28, 56 days (three cylinders at each age test). Also, water absorption for all mixes was conducted according to ASTM C-642 [39]. 


\section{Results and discussion}

\subsection{Compressive strength}

Compressive strength outcomes for all mixes in this study at different ages are presented in Fig. 2. The magnitude of compressive strength for all mixes with waste powdered replacement ( $80 \%$ glass $+20 \%$ ceramics) were found higher than to that of reference mix (without waste powdered replacement). Maximum strength was achieved for (MIX15) at all ages, which was $19.3 \%, 14.4 \%$, and $9.5 \%$ auxiliary than reference mix at ages 7, 28, and 56 days respectively. Variation pattern of compressive strength with the level of waste powdered replacement for 7, 28, and 56 days are directed in Fig. 3.

The increment of compressive strength for waste powdered as volumetric replacement from silica fume at 28 days are $8.1 \%, 10.2 \%, 14.4 \%, 8.3 \%$, and $2.3 \%$ for MIX05, MIX10, MIX15, MIX20, and MIX25, respectively. This trend somewhat was reported by earlier authors [40].

\subsection{Splitting strength}

Splitting strength outcomes for all mixes in this study at different ages are presented in Fig. 4. Similarity to compressive strength trend, the magnitude of splitting strength for

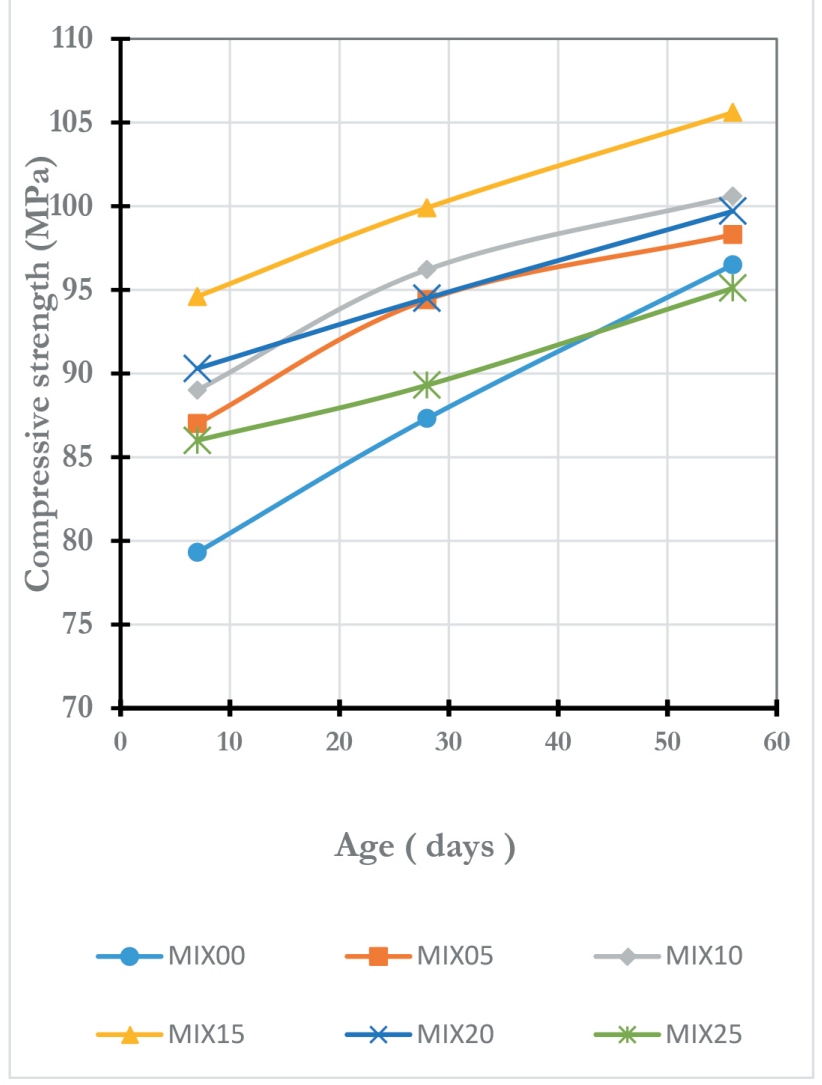

Fig. 2 Compressive strength results of reactive powder concrete at various ages all mixes with waste powdered replacement $(80 \%$ glass + $20 \%$ ceramics) were found higher than to that of reference mix (without waste powdered replacement). Maximum strength was achieved for (MIX15) at all ages, which was $30.8 \%, 14.8 \%$, and $20.3 \%$ auxiliary than reference mix at ages 7, 28, and 56 days respectively. Variation pattern of splitting strength with the level of waste powdered replacement for 7, 28 and 56 days are directed in Fig. 5.

The increment of splitting strength for waste powdered as volumetric replacement from silica fume at 28 days are $5.2 \%, 9.8 \%, 14.8 \%, 11.7 \%$, and $10.8 \%$ for MIX05, MIX10, MIX15, MIX20, and MIX25, respectively.

\subsection{Water absorption}

Water absorption outcomes for all mixes in this study at different ages are presented in Fig. 6 the results demonstrate that value of water absorption increases as the waste powdered materials replacement from silica fume increase. The increment percentage at age 7 days was $1.25 \%, 2.5 \%$, $4.4 \%, 6.9 \%$, and $10.7 \%$ for MIX05, MIX10, MIX15, MIX20, and MIX25 as compared to references mix

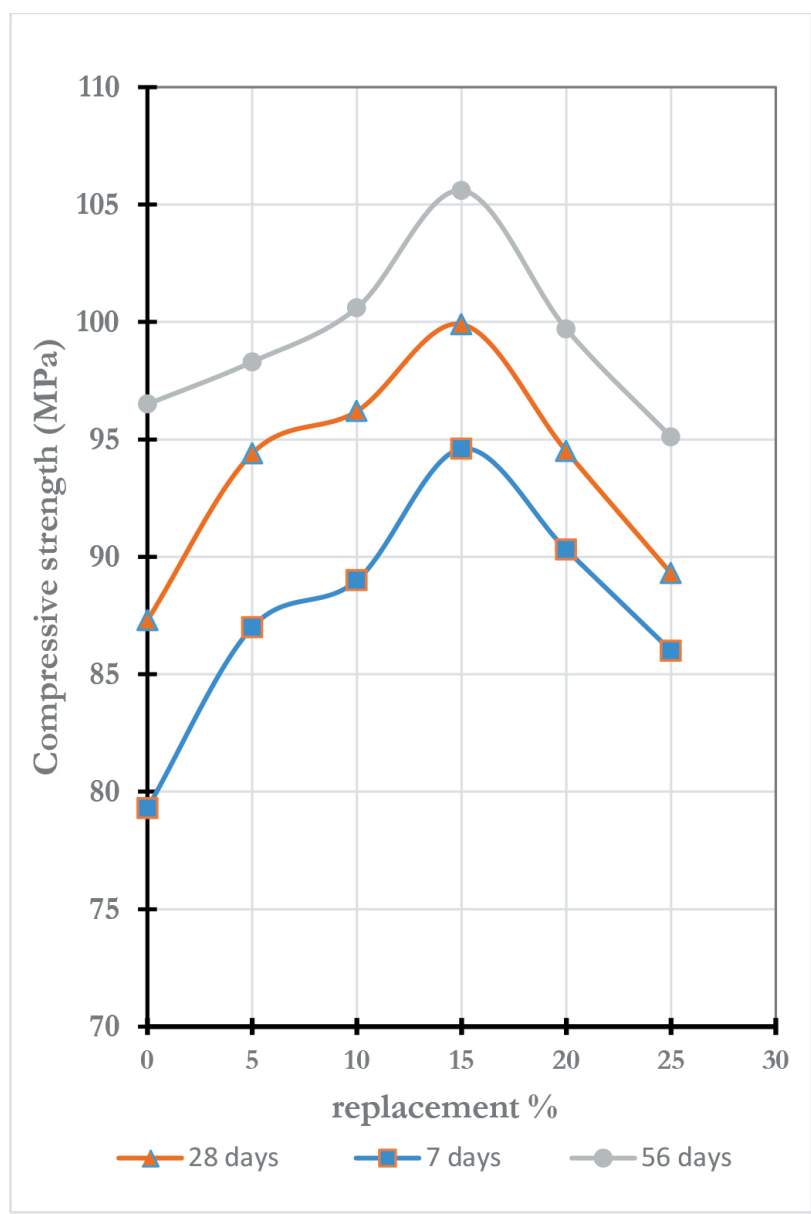

Fig. 3 Relationship between the compressive strength and replacement level at different ages 


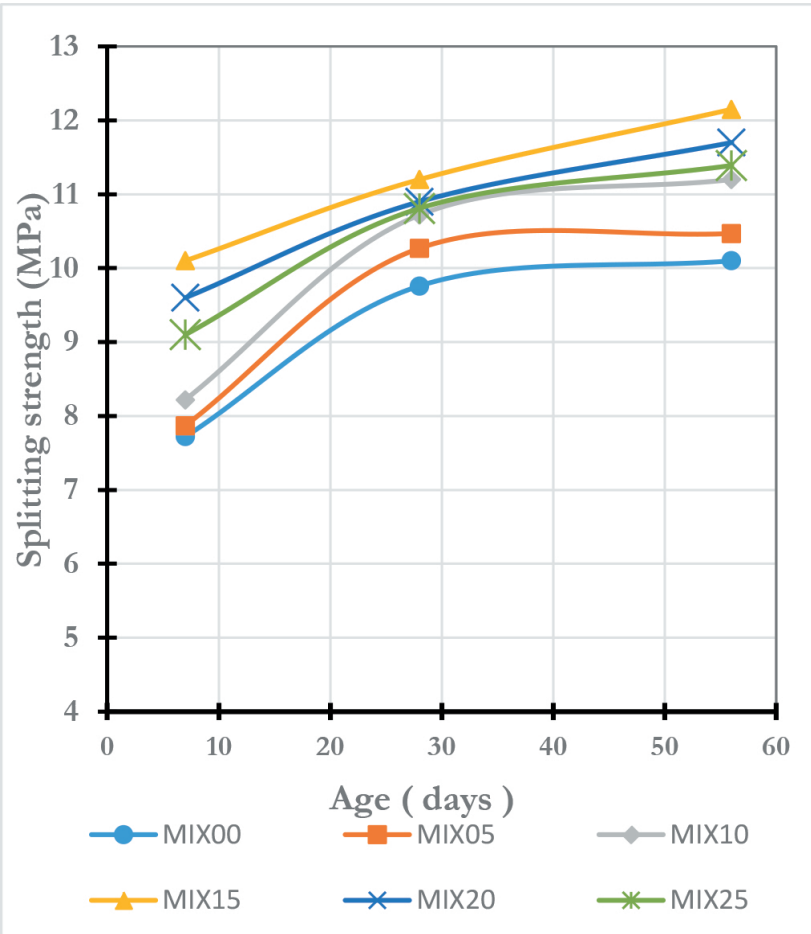

Fig. 4 Splitting strength results of reactive powder concrete at various ages

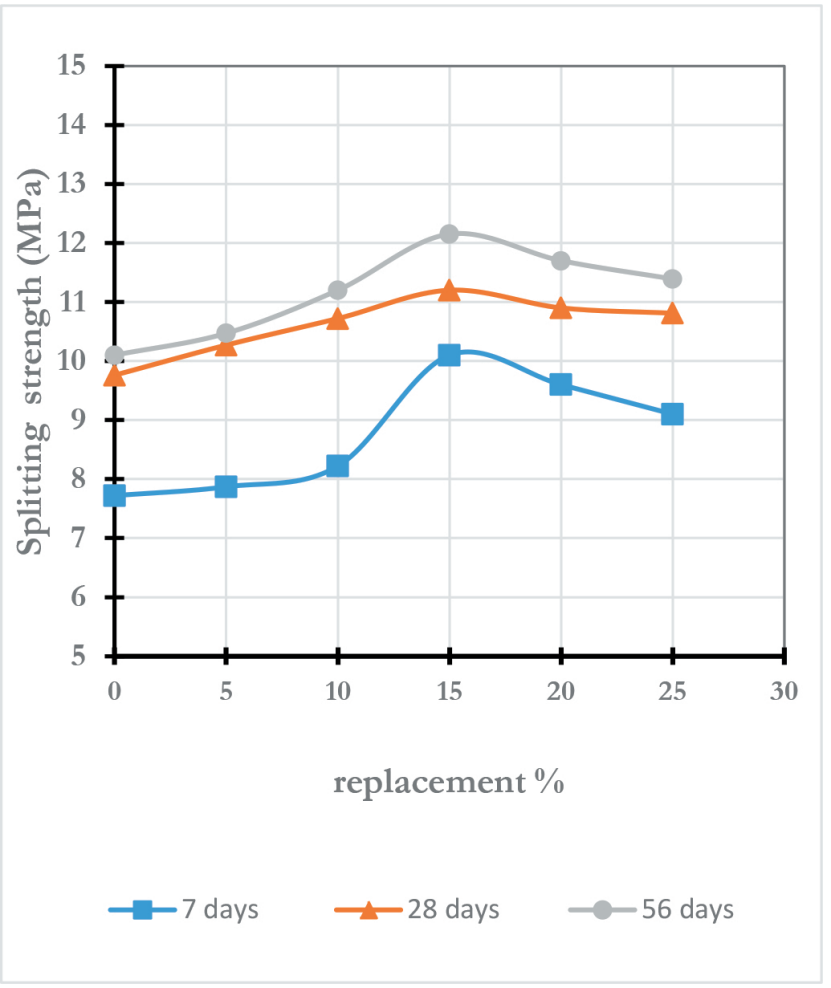

Fig.5 Relationship between the splitting strength and replacement level at different ages

without any replacement, respectively. The increment percentage at age 28 days was $1.6 \%, 2.9 \%, 4.5 \%, 6.4 \%$, and $10.5 \%$ for MIX05, MIX10, MIX15, MIX20, and MIX25

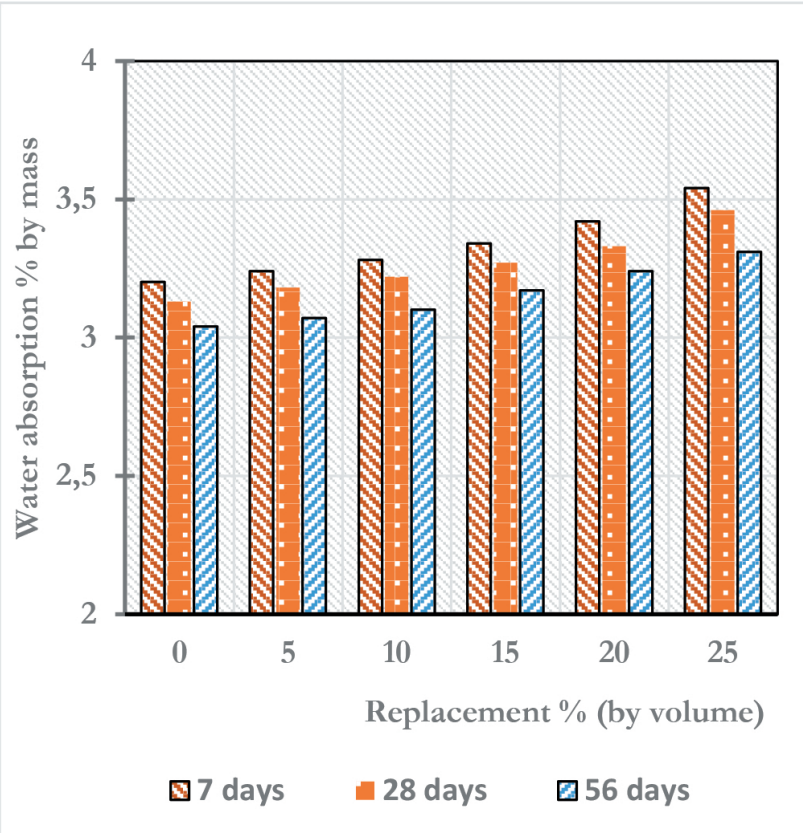

Fig. 6 Water absorption results of reactive powder concrete at various ages

as compared to references mix without any replacement, respectively. The increment percentage at age 56 days was $1.0 \%, 1.9 \%, 4.3 \%, 6.6 \%$, and $8.9 \%$ for MIX05, MIX10, MIX15, MIX20, and MIX25 as compared to references mix without any replacement, respectively.

\section{Conclusions}

After initiation the experimental work on simultaneously replacing of waste powdered materials (waste glass and waste ceramics tile) as partial of silica fume in modified reactive powder concrete and their detailed exploration, succeeding points could be concluded:

1. Powdered waste glass and powdered waste ceramics tile can be together utilized as pozzolanizc material in concrete replacement. The optimum mixing ratio for this pozzolanic material $80 \%$ glass and 20 ceramics.

2. The compressive strength of modified reactive powder concrete containing waste powdered material up to $25 \%$ replacement from silica fume higher than reference mix.

3. The splitting strength of modified reactive powder concrete containing waste powdered material up to $25 \%$ replacement from silica fume higher than reference mix at all ages.

4. The water absorption of modified reactive powder concrete increases as the content of waste powdered material increase. 
5. The optimum percent of replacement of waste powdered material from silica fume in reactive powder concrete is $15 \%$, due to the greatest enhancement in the compressive and splitting strengths of modified reactive powder concrete.

\section{References}

[1] Abid, M., Hou, X., Zheng, W., Hussain, R. R. "High temperature and residual properties of reactive powder concrete - A review", Construction and Building Materials, 147, pp. 339-351, 2017. https://doi.org/10.1016/j.conbuildmat.2017.04.083

[2] Richard, P., Cheyrezy, M. "Composition of reactive powder concretes", Cement and Concrete Research, 25(7), pp. 1501-1511, 1995. https://doi.org/10.1016/0008-8846(95)00144-2

[3] Cheyrezy, M., Maret, V., Frouin, L. "Microstructural analysis of RPC (Reactive Powder Concrete)", Cement and Concrete Research, 25(7), pp. 1491-1500, 1995.

https://doi.org/10.1016/0008-8846(95)00143-Z

[4] Cwirzen, A., Penttala, V., Vornanen, C. "Reactive powder based concretes: Mechanical properties, durability and hybrid use with OPC", Cement and Concrete Research, 38(10), pp. 1217-1226, 2008.

https://doi.org/10.1016/j.cemconres.2008.03.013

[5] Salahuddin, H., Qureshi, L. A., Nawaz, A., Raza, S. S. "Effect of recycled fine aggregates on performance of Reactive Powder Concrete", Construction and Building Materials, 243, Article No. 118223, 2020.

https://doi.org/10.1016/j.conbuildmat.2020.118223

[6] Borg, R. P., Hajek, P., Fernandez-Ordonez, D. "FIB Conference: Sustainable Concrete: Materials and Structures", IOP Conference Series: Materials Science and Engineering, 442, Article No. 011001, 2018.

https://doi.org/10.1088/1757-899X/442/1/011001

[7] Mohammed, S. D., Awad, H. K., Aboud, R. K. "Compressive Strength Performance of Reactive Powder Concrete Using Different Types of Materials as a Partial Replacement of Fine Aggregate", Key Engineering Materials, 857, pp. 39-47, 2020.

https://doi.org/10.4028/www.scientific.net/KEM.857.39

[8] Zeghad, M., Mitterpach, J., Safi, B., Amrane, B., Saidi, M. "Reuse of Refractory Brick Wastes (RBW) as a Supplementary Cementitious Material in a Concrete", Periodica Polytechnica Civil Engineering, 61(1), pp. 75-80, 2017.

https://doi.org/10.3311/PPci.8194

[9] Abed, M., Nemes, R. "Mechanical Properties of Recycled Aggregate Self-Compacting High Strength Concrete Utilizing Waste Fly Ash, Cellular Concrete and Perlite Powders", Periodica Polytechnica Civil Engineering, 63(1), pp. 266-277, 2019. https://doi.org/10.3311/PPci.13136

[10] G. Kászonyi "The strength, deformation and thermomechanic properties of crushed brick aggregate light-weight concrete", Periodica Polytechnica Civil Engineering, 33(1-2), pp. 59-69, 1989. [online] Available at: https://pp.bme.hu/ci/article/view/3917
6. There is opportunity for recycling waste materials like glass and ceramics tiles as partially replacement from silica fume for producing modified reactive powder concrete.

[11] Seitl, S., Miarka, P., Šimonová, H., Frantík, P., Keršner, Z., Domski, J., Katzer, J. "Change of Fatigue and Mechanical Fracture Properties of a Cement Composite due to Partial Replacement of Aggregate by Red Ceramic Waste", Periodica Polytechnica Civil Engineering, 63(1), pp. 152-159, 2019. https://doi.org/10.3311/PPci.12450

[12] Cabrera-Covarrubias, F. G., Gómez-Soberón, J. M., Almaral-Sánchez, J. L., Corral-Higuera, R., Gómez-Soberón, M. C. "Implementation of Interaction Diagram of the Properties in Fresh for Mortars with Ceramic Aggregates", Periodica Polytechnica Civil Engineering, 61(2), pp. 335-340, 2016. https://doi.org/10.3311/PPci.9651

[13] Zhu, P., Mao, X., Qu, W., Li, Z., Ma, Z. J. "Investigation of using recycled powder from waste of clay bricks and cement solids in reactive powder concrete", Construction and Building Materials, 113, pp. 246-254, 2016. https://doi.org/10.1016/j.conbuildmat.2016.03.040

[14] Kushartomo, W., Bali, I., Sulaiman, B. "Mechanical Behavior of Reactive Powder Concrete with Glass Powder Substitute", Procedia Engineering, 125, pp. 617-622, 2015. https://doi.org/10.1016/j.proeng.2015.11.082

[15] Asteray, D. B., Oyawa, W. O., Shitote, S. M. "Compressive and Flexural Strength of Recycled Reactive Powder Concrete Containing Finely Dispersed Local Wastes", Open Journal of Civil Engineering, 8(1), pp. 12-26, 2018. https://doi.org/10.4236/ojce.2018.81002

[16] Demiss, B. A., Oyawa, W. O., Shitote, S. M. "Mechanical and microstructural properties of recycled reactive powder concrete containing waste glass powder and fly ash at standard curing", Cogent Engineering, 5(1), Article No. 1464877, 2018. https://doi.org/10.1080/23311916.2018.1464877

[17] Asteray, B., Oyawa, W., Shitote, S. "Experimental Investigation on Compressive Strength of Recycled Reactive Powder Concrete Containing Glass Powder and Rice Husk Ash", Journal of Civil Engineering Research, 7(4), pp. 124-129, 2017. [online] Available at: http://article.sapub.org/10.5923.j.jce.20170704.03.html

[18] Mao, X., Qu, W., Zhu, P. "Mixture Optimization of Green Reactive Powder Concrete with Recycled Powder", Journal of Materials in Civil Engineering, 31(5), Article No. 04019033, 2019. https://doi.org/10.1061/(ASCE)MT.1943-5533.0002663

[19] Mohammed, V. B., Hama, S. M., Aziz, K. I. "Assessment Strength Properties of Modified Reactive Powder Concrete by Adding Waste Bricks", In: 2019 12th International Conference on Developments in eSystems Engineering (DeSE), Kazan, Russia, 2019, pp. 83-87. https://doi.org/10.1109/DeSE.2019.00025 
[20] Islam, A., Yesmin, S. "Mechanical Properties of Recycle Reactive Powder Concrete (RRPC) Containing Combined Effect of Coarse Aggregate \& Dispersed Local Materials", International Journal of Research Publications, 50(1), 2020. [online] Available at: https:// ijrp.org/paper-detail/1048

[21] Liu, T., Wei, H., Zou, D., Zhou, A., Jian, H. "Utilization of waste cathode ray tube funnel glass for ultra-high performance concrete", Journal of Cleaner Production, 249, Article No. 119333, 2020. https://doi.org/10.1016/j.jclepro.2019.119333

[22] ASTM "ASTM C1240 - 20 Standard Specification for Silica Fume Used in Cementitious Mixtures", ASTM International, West Conshohocken, PA, USA, 2020. https://doi.org/10.1520/C1240-20

[23] ASTM "ASTM C150/C150M - 20 Standard Specification for Portland Cement", ASTM International, West Conshohocken, PA, USA, 2020. https://doi.org/10.1520/C0150_C0150M-20

[24] ASTM "ASTM C33/C33M - 18 Standard Specification for Concrete Aggregates", ASTM International, West Conshohocken, PA, USA, 2018.

https://doi.org/10.1520/C0033 C0033M-18

[25] Yaowakulpattana, P., Wakasugi, T., Kondo, S., Kadono, K. "Effect of Alkaline and Alkaline-Earth Metal Oxides Addition on the Glass Formation and Crystallization of ZnO-Al2O3-SiO2 Glasses", Engineering Journal, 19(3), pp. 21-34, 2015. https://doi.org/10.4186/ej.2015.19.3.21

[26] Pitarch, A. M., Reig, L., Tomás, A. E., Forcada, G., Soriano, L., Borrachero, M. V., Payá, J., Monzó, J. M. "Pozzolanic activity of tiles, bricks and ceramic sanitary-ware in eco-friendly Portland blended cements", Journal of Cleaner Production, 279, Article No. 123713, 2021.

https://doi.org/10.1016/j.jclepro.2020.123713

[27] ASTM "ASTM C494/C494M - 19 Standard Specification for Chemical Admixtures for Concrete", ASTM International, West Conshohocken, PA, USA, 2019.

https://doi.org/10.1520/C0494 C0494M-19

[28] ASTM "ASTM C618 - 19 Standard Specification for Coal Fly Ash and Raw or Calcined Natural Pozzolan for Use in Concrete", ASTM International, West Conshohocken, PA, USA, 2019. https://doi.org/10.1520/C0618-19

[29] ASTM "ASTM C311/C311M - 18 Standard Test Methods for Sampling and Testing Fly Ash or Natural Pozzolans for Use in Portland-Cement Concrete", ASTM International, West Conshohocken, PA, USA, 2018. https://doi.org/10.1520/C0311_C0311M-18

[30] Radhi, M. S., Abdul Rasoul, Z. M. R., Ridha Mahmmod, L. M. "Utilization of Pulverized Local Wastes for Production Sustainable Reactive Powder Concrete", IOP Conference Series: Materials Science and Engineering, 518, Article No. 022052, 2019. https://doi.org/10.1088/1757-899X/518/2/022052
[31] Alsaad, A. J., Radhi, M. S., Taher, M. J. "Eco-friendly Utilizing of Iron Filings in Production Reactive Powder Concrete", IOP Conference Series: Materials Science and Engineering, 518, Article No. 022051, 2019. https://doi.org/10.1088/1757-899X/518/2/022051

[32] Taher, M. J., Alsaad, A. J., Radhi, M. S. "Comparability Study on the Effects of Curing Approaches on the Mechanical Behaviours of Reactive Powder Concrete", IOP Conference Series: Materials Science and Engineering, 671, Article No. 012141, 2020.1 https://oi.org/10.1088/1757-899X/671/1/012141

[33] Hamid, H. A., Mohammed, S. D. "Flexural Moment Capacity Evaluation of Reinforced RPC Two-way Slabs", Engineering Journal, 23(1), pp. 109-121, 2019. https://doi.org/10.4186/ej.2019.23.1.109

[34] Tuama, W. K., Kadhum, M. M., Alwash, N. A., Al-Khafaji, Z. S., Abdulraheem, M. S. "RPC Effect of Crude Oil Products on the Mechanical Characteristics of Reactive-Powder and NormalStrength Concrete", Periodica Polytechnica Civil Engineering, 64(2), pp. 422-429, 2020. https://doi.org/10.3311/PPci.15580

[35] Nasr, M. S., Hasan, Z. A., Abed, M. K., Dhahir, M. K., Najim, W. N., Shubbar, A. A., Habeeb, Z. D. "Utilization of High Volume Fraction of Binary Combinations of Supplementary Cementitious Materials in the Production of Reactive Powder Concrete", Periodica Polytechnica Civil Engineering, 65(1), pp. 335-343, 2021. https://doi.org/10.3311/PPci.16242

[36] Hiremath, P. N., Yaragal, S. C. "Influence of mixing method, speed and duration on the fresh and hardened properties of Reactive Powder Concrete", Construction and Building Materials, 141, pp. 271-288, 2017. https://doi.org/10.1016/j.conbuildmat.2017.03.009

[37] ASTM "ASTM C109/C109M - 20b Standard Test Method for Compressive Strength of Hydraulic Cement Mortars (Using 2-in. or [50 mm] Cube Specimens)", ASTM International, West Conshohocken, PA, USA, 2020. https://doi.org/10.1520/C0109_C0109M-20B

[38] ASTM "ASTM C496/C496M - 17 Standard Test Method for Splitting Tensile Strength of Cylindrical Concrete Specimens", ASTM International, West Conshohocken, PA, USA, 2017. https://doi.org/10.1520/C0496_C0496M-17

[39] ASTM "ASTM C642 - 13 Standard Test Method for Density, Absorption, and Voids in Hardened Concrete", ASTM International, West Conshohocken, PA, USA, 2013. https://doi.org/10.1520/C0642-13

[40] Gamal, I. K., Elsayed, K. M., Makhlouf, M. H., Alaa, M. "Properties of Reactive Powder Concrete Using Local Materials and Various Curing Conditions", European Journal of Engineering Research and Science, 4(6), pp. 74-83, 2019. https://doi.org/10.24018/ejers.2019.4.6.1370 